\title{
APLIKASI LATIH VOKAL DENGAN MENGGUNAKAN METODE HARMONIC PRODUCT SPECTRUM (HPS) DAN BOYER MOORE BERBASIS ANDROID
}

\author{
Vonny Afriyona Egisthi \\ Fakultas Teknik, Program Studi Teknik Informatika \\ Universitas Bengkulu \\ Email: vonny.egisthi@gmail.com \\ Desi Andreswari \\ Universitas Bengkulu \\ Email: dezieandrez@yahoo.co.id \\ Yudi Setiawan \\ Universitas Bengkulu \\ Email: ys.teknik@unib.ac.id
}

\begin{abstract}
ABSTRAK
Teknik vokal adalah cara memproduksi suara yang baik dan benar, sehingga suara yang keluar terdengar jelas, indah, merdu, dan nyaring, kebanyakan masyarakat masih kesulitan dalam mempelajari teknik vokal dan menentukan kursus vokal yang sesuai. Penelitian ini akan membangun sebuah aplikasi latih vokal yang dapat digunakan kapan saja. Metode HPS (Harmonic Product Spectrum) digunakan untuk melakukan pendeteksian nada pada suara inputan dan metode Boyer Moore digunakan untuk melakukan penentuan skor pada ujian karaoke. Hasil akhir dari aplikasi ini adalah dapat membantu pengguna dalam mempelajari teknik vokal dengan mudah, serta dapat mengevaluasi kemampuan bernyanyi dengan ujian karaoke. Pada penelitian ini dilakukan pengujian black box dengan teknik equivalence partitioning dengan teknik pengujian yang membagi domain input, menentukan kasus pengujian dengan mengungkapkan kelas-kelas kesalahan. Dari hasil uji kelayakan sistem yang dilakukan menggunakan kuesioner didapatkan $68.33 \%$ untuk pengujian fungsional sistem, $67.05 \%$ pengujian antarmuka dan pengaksesan, dan $69.33 \%$ untuk pengujian manfaat sistem.
\end{abstract}

Kata kunci: latih vokal, harmonic product spectrum (HPS), boyer moore.

\begin{abstract}
Vocal technique is a way of producing sound is good and right, so that the sound comes out sounding clear, beautiful, melodious and sonorous, most people are still difficulties in studying vocal technique and vocal determine the appropriate course. This study will build a vocal trainer app that can be used anytime. Method HPS (Harmonic Product Spectrum) is used to make the detection tone in the voice input and Boyer Moore method used to perform on the exam scoring karaoke. The end result of this application is to help users in learning vocal techniques with ease, and can evaluate the ability to sing karaoke exam. In this research, black box testing technique that equivalence partitioning testing technique that divides the input domain, specify test cases by revealing error classes. From the results of the feasibility test conducted using a questionnaire system obtained $68.33 \%$ for functional testing system, $67.05 \%$ and accessing interface testing, and $69.33 \%$ for the test system benefits.
\end{abstract}

Keywords: vocal trainer, harmonic product spectrum (HPS), boyer moore.

\section{PENDAHULUAN}

Bernyanyi merupakan salah satu kegiatan yang dapat memenuhi kebutuhan psikologi manusia karena bernyanyi dapat mengaplikasikan perasaan yang sedang dialami. Selain untuk menghibur diri, bernyanyi juga berdampak positif untuk kesehatan seperti menjadikan pernafasan lebih baik, mengoksidasi darah, merangsang aktifitas otak, melepaskan hormon bahagia, mengurangi stres, membangun kepercayaaan diri, meningkatkan kreatifitas, menciptakan suara yang bertenaga dan membuat seseorang merasa fantastis. 
Untuk dapat bernyanyi dengan baik dan benar dibutuhkan suatu sarana pembelajaran seperti sekolah vokal atau kursus vokal baik formal maupun non formal. Hal ini tentu membutuhkan waktu, tenaga dan biaya yang tidak semua orang dapat memenuhinya Tetapi khususnya untuk di Bengkulu, sekolah vokal atau kursus vokal sangat sulit ditemui bahkan hanya terdapat dua sekolah vokal yang masih aktif tetapi tidak memiliki banyak peserta didik. Informasi mengenai sekolah atau kursus vokal tersebut juga tidak dapat ditemui baik melalui web maupun media cetak lainnya. Sebagian orang yang tahu sekolah vokal atau kursus tersebut hanya dari mulut ke mulut saja, sehingga kita tidak tahu apakah kursus vokal tersebut memang bagus atau tidak. Adanya keadaan seperti itu semakin menyulitkan kita untuk mencari sekolah atau kursus vokal di Bengkulu.

Ketepatan nada dalam bernyanyi menjadi poin utama untuk menghasilkan nyanyian yang sempurna. Sebelum bisa menyanyikan nada dengan tepat, seseorang harus mempelajari terlebih dahulu tentang nada dasar. Pada kursus vokal tentunya peran seorang pelatih sangat penting, untuk memberi arahan apakah nada yang di ucapkan sudah benar atau belum. Tetapi untuk seseorang yang hanya belajar secara otodidak, tidak ada yang bisa memberi tahu apakah itu benar atau salah.

Harmonic Product Spectrum (HPS) merupakan salah satu metode yang dapat digunakan untuk pendeteksian nada. Pendeteksian nada dilakukan dengan cara merekam suara sambil menyebutkan nadanada dasar. Nantinya kita akan mengetahui apakah nada yang disebutkan sudah benar atau tidak. Metode ini merupakan metode pitch detection algorithm yang paling simpel dan dapat bekerja dengan baik dalam berbagai kondisi [1].

Untuk melihat sejauh mana seseorang sudah menguasai teknik vokal dengan baik dan benar, maka diperlukan suatu pengujian. Seseorang dapat menguji kemampuan bernyanyinya dan mengevaluasi kesalahannya dengan melihat score setelah dia menyanyikan lagu tersebut. Salah satu metode yang bisa digunakan untuk penentuan score pada hal ini adalah algoritma pencocokan string, Boyer Moore. Proses metode Boyer Moore pada penelitian ini adalah dengan mencocokan suara vocal yang diberikan oleh penyanyi karaoke dengan sejumlah nada yang ada pada sejumlah track pada lagu yang sedang dimainkan. Suara vokal dari penyanyi bisa dipandang sebagai pattern dan kumpulan suara dari musik itu sendiri dapat dipandang sebagai string.

Dengan permasalahan tersebut, maka peneliti ingin membangun sebuah sarana pembelajaran vokal menggunakan perangkat mobile, untuk memberikan kemudahan pengguna khususnya masyarakat Bengkulu yang ingin berlatih vokal secara mandiri atau otodidak. Sehingga permasalahan yang selama ini menjadi kendala bisa teratasi dengan mudah.

\section{LANDASAN TEORI}

\subsection{Teknik Vokal Bernyanyi}

Teknik vokal adalah cara memproduksi suara yang baik dan benar, sehingga suara yang keluar terdengar jelas, indah, merdu, dan nyaring. Menyanyikan sebuah lagu diperlukan latihan vokal agar dapat mengetahui tinggi rendahnya sebuah nada, sehingga terjadi suatu keselarasan antara nada dan suara. Beberapa unsur dasar dalam melatih vokal yang harus dikuasai adalah latihan breath control, artikulasi dan notasi angka [2].

\subsection{Metode Harmonic Product Spectrum}

Harmonic Product Spectrum merupakan metode pitch detection algorithm yang paling simpel dan bekerja dengan baik dalam berbagai kondisi (Garreth, 2003). Harmonic Product Spectrum (HPS) memerlukan beberapa proses pengolahan dari audio file yaitu windowing dan Fast Fourier Transform (FFT) [3].

Ketika menggunakan FFT untuk mengukur frekuensi dari data, maka harus menentukan dasar analisa pada sebuah data yang pasti. FFT mengasumsikan bahwa data yang tetap adalah sebuah periode dari period signal. Bagi FFT time-domain dan frequency-domain adalah perputaran yang sama, sehingga titik terakhir dari time waveform dianggap berhubungan. Sehingga keterbatasan dalam sampling record menghasilkan waveform yang terpotong dengan perbedaan karakter dari sinyal aslinya, dan keterbatasan ini membuat perubahan yang tajam dalam pengukuran data. Untuk mengurangi efek perubahan ini, kita bisa menggunakan fungsi Window untuk sinyal dalam time-domain sebelum diproses menuju FFT. A-D converter untuk mengubah sinyal analog menjadi digital sebelum disimpan dalam komputer. Proses komputasi spektrum dari sinyal yang telah direkam adalah menggunakan Fast Fourier Trasform. Pada gambar berikut ini merupakan hasil dari Hamming Window atau yang disebut juga proses pengubahan sinyal [4]. 
Harmonic Product Spectrum digunakan untuk melakukan analisis dan penentuan akurasi. Tahapan pertama dalam algoritma Harmonic Product Spectrum ini adalah proses FFT (Fast Fourier Transform) yaitu sinyal dalam domain waktu kemudian diubah ke domain frekuensi untuk melihat range frekuensinya. Proses ini bertujuan untuk menentukan range frekuansi yang memiliki energi paling maksimum.

\subsection{Metode Boyer Moore}

Ide utama dari algoritma ini adalah dengan melakukan pencocokan dari paling kanan string yang dicari. Dengan menggunakan algoritma ini, secara rata-rata proses pencarian akan lebih cepat dibandingkan dengan proses pencarian lainnya. Ide dibalik algoritma ini adalah bahwa dengan memulai pencocokan karakter dari kanan, dan bukan dari kiri, maka akan lebih banyak informasi yang didapat.

Dalam pencarian Boyer-Moore, proses awal yang dilakukan adalah penempatan window dari pattern di text yang tersedia. Proses pencarian dimulai dari karakter paling kanan pattern. Setiap karakter akan dibandingkan satu per satu. Jika terjadi ketidakcocokan, maka akan dicek nilai pergeseran yang mungkin dilakukan. Nilai terbesar yang didapat akan diambil dan pergeseran window akan dilakukan sesuai dengan nilai tersebut [5].

\subsection{Eclips}

Eclipse yang diluncurkan IBM pada tanggal 5 November 2001 merupakan sebuah IDE yang gratis dan open source atau yang dapat dikembangkan dan digunakan untuk membangun sebuah program komputer dan dapat dijalankan disemua platform.

\subsection{Android}

Menurut Nazrudin Safaat H (2011: 1), “Android adalah sebuah sistem operasi untuk perangkat mobile berbasis linux yang mencakup sistem operasi, middleware, dan aplikasi”. Android adalah sistem operasi untuk telepon seluler yang berbasis Linux. Android menyediakan platform terbuka bagi para pengembang untuk membuat aplikasi mereka sendiri.

\subsection{UML (Unified Modeling Language)}

Unifed Modeling Language (UML) adalah keluarga notasi grafis yang didukung oleh meta-model tunggal, yang membantu pendeskripsian dan desain sistem perangkat lunak, khususnya sistem yang dibangun menggunakan pemrograman berorientasi objek (OO). Berdasarkan sifatnya, jenis diagram UML ada 9, diantaranya class diagram, sequence diagram, usecase diagram, activity diagram, object diagram, component diagram, collaboration diagram, dan deployment diagram [6].

\section{METODOLOGI PENELITIAN}

\subsection{Jenis Penelitian}

Jenis penelitian yang dilakukan adalah penelitian terapan (Applied Research). Penelitan terapan yaitu penelitian yang dilakukan berkenaan dengan kenyataan-kenyataan praktis, penerapan, dan pengembangan ilmu pengetahuan yang dihasilkan oleh penelitian dasar dalam kehidupan yang bersifat nyata.

\subsection{Teknik Pengumpulan Data}

Dalam mengumpulkan data, teknik pengumpulan data yang digunakan dalam penelitian ini ada 3 yaitu dengan metode:

\subsubsection{Studi Pustaka}

Studi kepustakaan diilakukan dengan mengumpulkan data dan informasi yang digunakan sebagai acuan dalam pembuatan aplikasi latih vokal dengan metode HPS (Harmonic Product Spectrum) dan metode Boyer Moore. Data dan informasi dapat berupa buku-buku, laporan penelitian, skripsi, jurnal dan sumber-sumber tertulis lainnya yang berhubungan dengan pemahaman yang digunakan dalam penelitian ini. 


\subsubsection{Studi Analisis}

Melakukan analisis terhadap masalah yang dikaji yaitu kesulitannya seseorang untuk mencari guru vokal yang sesuai dan benar-benar memahami tentang teknik vokal tersebut serta kesulitannya seseorang untuk menentukan waktu latihan vokal yang cocok.

\subsubsection{Wawancara}

Melakukan tanya jawab mengenai aplikasi latih vokal yang dibangun, apakah sudah membantu memberikan pelatihan vokal secara otodidak dan praktis. Wawancara dilakukan langsung dengan pelatih vokal yang ada di Bengkulu.

\subsection{Metode Pengembangan Sistem}

Pengembangan sistem aplikasi latih vokal dalam tugas akhir ini menggunakan model Waterfall. Model Waterfall mengusulkan sebuah pendekatan kepada perkembangan perangkat lunak sistematik dan sekuensial yang mulai pada tingkat dan kemajuan sistem pada seluruh analisis, desain, kode, pengujian dan pemeliharaan. Adapun penjelasan langkah-langkah yang dilakukan dalam pengembangan sistem ini secara garis besar adalah sebagai berikut:

\subsubsection{Analisis Kebutuhan}

Sistem yang akan dibuat memerlukan masukan, keluaran dan kebutuhan interface. Tujuan analisis kebutuhan adalah sebagai batasan dari sistem yang akan dibuat, menentukan kemampuan dan fungsi sistem sesuai dengan kebutuhan user, dan fasilitas-fasilitas yang merupakan nilai tambah yang ada pada sistem yang dibangun.

\subsubsection{Perancangan Sistem}

Perancangan sistem ini merupakan tahap konseptualisasi, yaitu suatu tahap yang mengharuskan analisis dalam perancangan sistem (perangkat lunak) untuk berusaha mengetahui mengenai hal-hal yang menjadi kebutuhan dan harapan pengguna, sehingga nanti sistem yang dibuat memang dibutuhkan oleh user serta memuaskan kebutuhan dan harapannya. Diagram yang digunakan dalam perancangan aplikasi ini adalah Unified Language Diagram.

1) Implementasi

Dalam pembuatan aplikasi, tahap ini merupakan tahapan secara nyata dalam pengerjaan aplikasi. Aplikasi latih vokal dengan menggunakan metode Harmonic Product Spectrum (HPS) dan metode Boyer Moore akan dibuat sesuai dengan kebutuhan pengguna oleh penulis pada tahapan ini aplikasi yang akan dibangun berbasis android.

2) Pengujian Sistem

Proses pengujian yang dilakukan pada aplikasi yang dibuat menggunakan metode pengujian black box testing. Pengujian black box atau pengujian fungsional adalah pengujian kondisi yang dibangun berdasarkan fungsional dari program atau sistem. Pada pengujian black box dibutuhkan informasi mengenai data masukan dan sasaran keluaran tanpa harus mengetahui bagaimana program atau sistem tersebut bekerja [8].

Adapun jenis pengujian black box yang akan digunakan yaitu Equivalence Partioning, yaitu metode yang membagi domain masukan dari suatu program ke dalam kelas-kelas data berdasarkan pada premis masukan dan keluaran dari suatu komponen yang dipartisi ke dalam kelas-kelas, menurut spesifikasi dari komponen tersebut, yang akan diperlakukan sama (ekuivalen) oleh komponen tersebut.

3) Penggunaan dan Pemeliharaan

Setelah sistem selesai maka pengguna akan menggunakan sistem. Jika terdapat pengembangan fungsional dari sistem yang diinginkan oleh pengguna, maka akan dilakukannya pemeliharaan dengan cara memperbaiki sistem jika terjadi kerusakan atau kesalahan pada sistem.

\section{ANALISIS DAN PERANCANGAN}

\subsection{Analisis Sistem}

Secara garis besar cara kerja sistem yang dibangun ditampilkan dalam Gambar 1 berikut. 


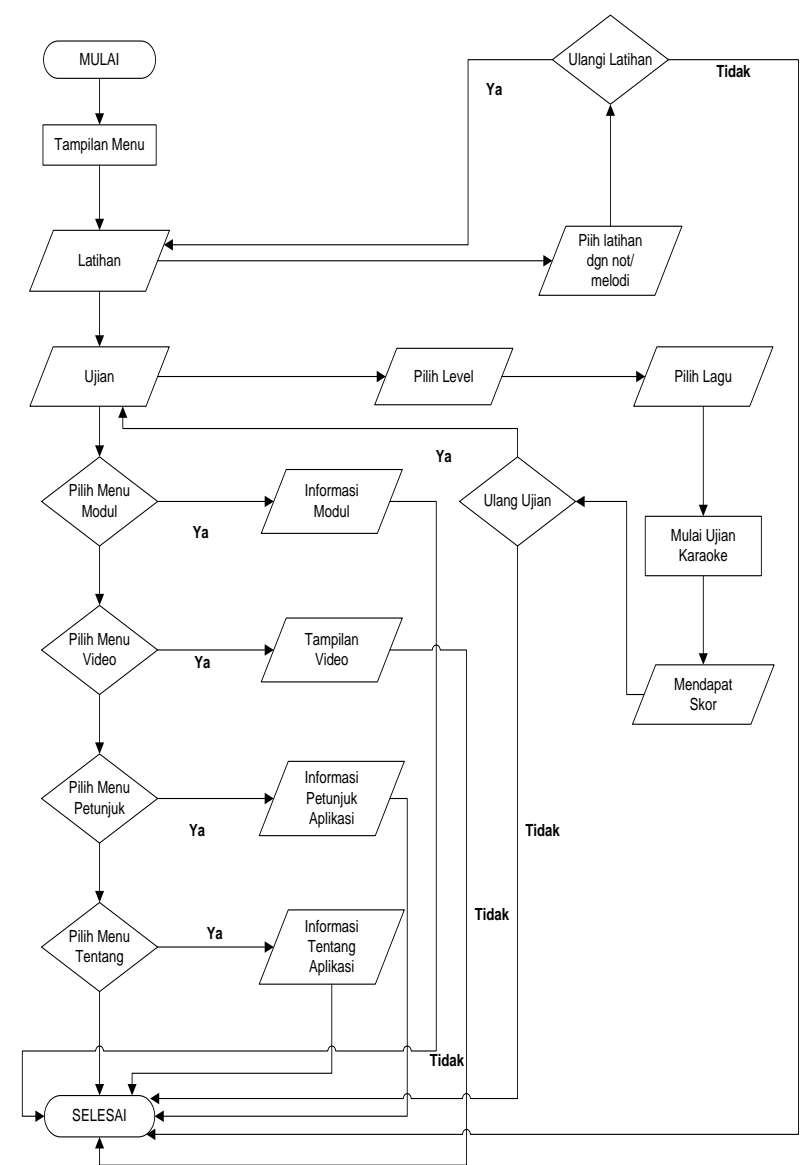

Gambar 1. Diagram Alir Kerja Sistem

\subsection{Perancangan Model UML (Unified Modeling Language)}

Perancangan model UML ditunjukkan untuk memberikan gambaran secara umum tentang sistem yang akan dibangun. Perancangan sistem Aplikasi Latih Vokal Dengan Menggunakan Metode Harmonic Product Spectrum (HPS) dan Boyer Moore Berbasis Android ini menggunakan model diagram UML, yaitu:

\subsubsection{Usecase Diagram}

Use case diagram merupakan pemodelan untuk perilaku sistem informasi yang akan dibuat. Use case mendeskripsikan sebuah interaksi antara satu atau lebih actor dengan sistem informasi yang akan dibuat.

Tabel 1. Kegiatan aktor dan interaksinya dengan sistem

\begin{tabular}{cl}
\hline Aktor & \multicolumn{1}{c}{ Interaksi } \\
\hline Pengguna & Pengguna dapat memilih latihan dan mempelajari tangga nada. \\
& Modul berisi tentang teknik vokal serta tips-tips. \\
& Pengguna dapat melihat video tutorial latihan vokal. \\
& Pengguna dapat mengikuti ujian, kemudian memilih level dan \\
& lagu yang akan dinyanyikan serta dapat merekam suara \\
& Pengguna dapat melihat bantuan dari aplikasi \\
& Pengguna dapat melihat tentang aplikasi. \\
\hline
\end{tabular}




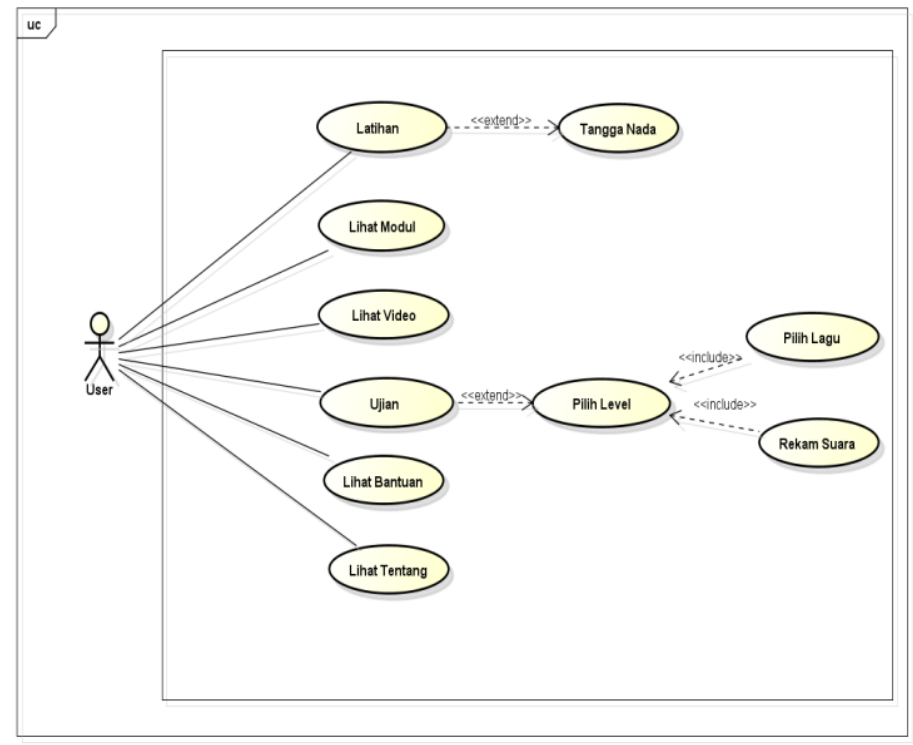

Gambar 2. Usecase Diagram

\subsubsection{Class Diagram}

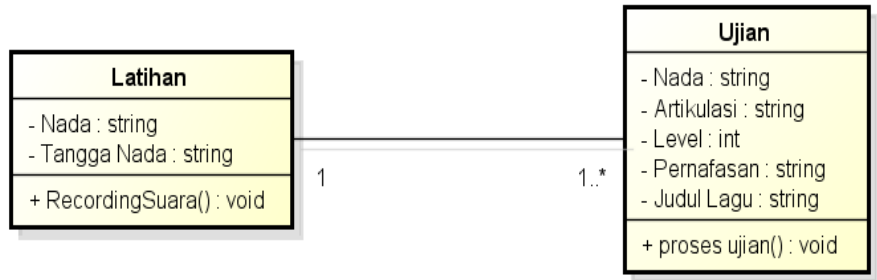

Gambar 3. Class Diagram Latih Vokal

Pada Gambar 3 komponen pada class diagram terdiri dari Class, attributes dan Operations. Class Diagram latih vokal terdiri dari 2 kelas yaitu kelas latihan dan kelas ujian. Kelas latihan mempunyai hubungan relasi $1 . . . .1 *$ dengan kelas ujian artinya pengguna dapat melakukan ujian secara berulang kali. Pada Class latihan memiliki atribut nada dan tangga nada dan memiliki objek berupa recording suara. Pada Class Ujian memiliki atribut nada, artikulasi, level, pernafasan dan judul lagu. Class ujian memiliki objek proses ujian.

\subsubsection{Activity Diagram}

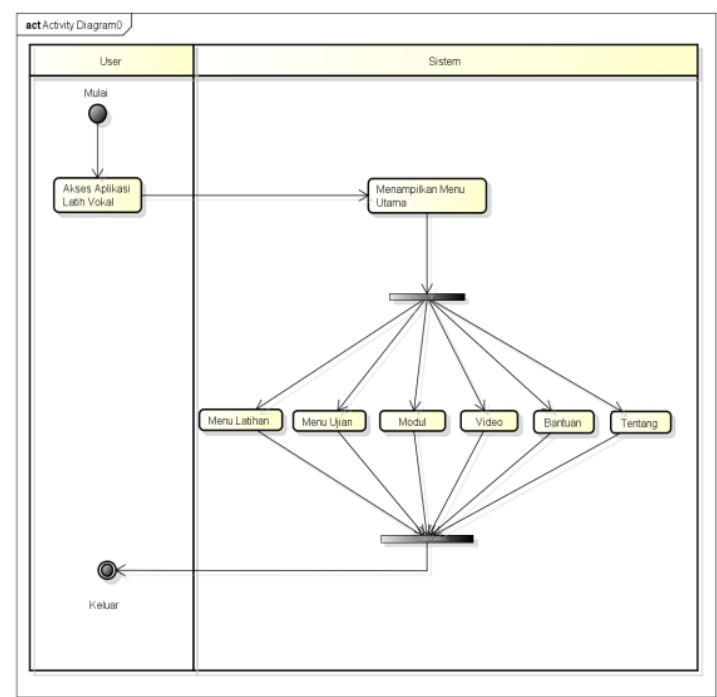

Gambar 4. Activity Diagram Latih Vokal 
Pada Gambar 4 menunjukkan keseluruhan dari kerja sistem. Pada aplikasi terdapat beberapa menu yaitu menu latihan, ujian, modul, video, bantuan dan tentang. Pada menu latihan berisi tentang latihan pengenalan tangga nada yang dilatih dengan not dan melodi. Menu ujian yaitu pengguna dapat mengukur sejauh mana teknik vokal yang dikuasai dengan menampilkan beberapa lagu serta skor dari ujian yang dilakukan. Pada modul berisi tentang penjelasan teknik vokal beserta tips yang berhubungan dengan vokal. Menu video menampilkan beberapa buah video tutor tentang teknik vokal secara praktek, sehingga bisa langsung dipraktekkan pengguna dimana saja. Pada menu bantuan berisi informasi mengenai cara penggunaan aplikasi, dan pada menu tentang berisis mengenai informasi sistem.

\subsubsection{Sequence Diagram}

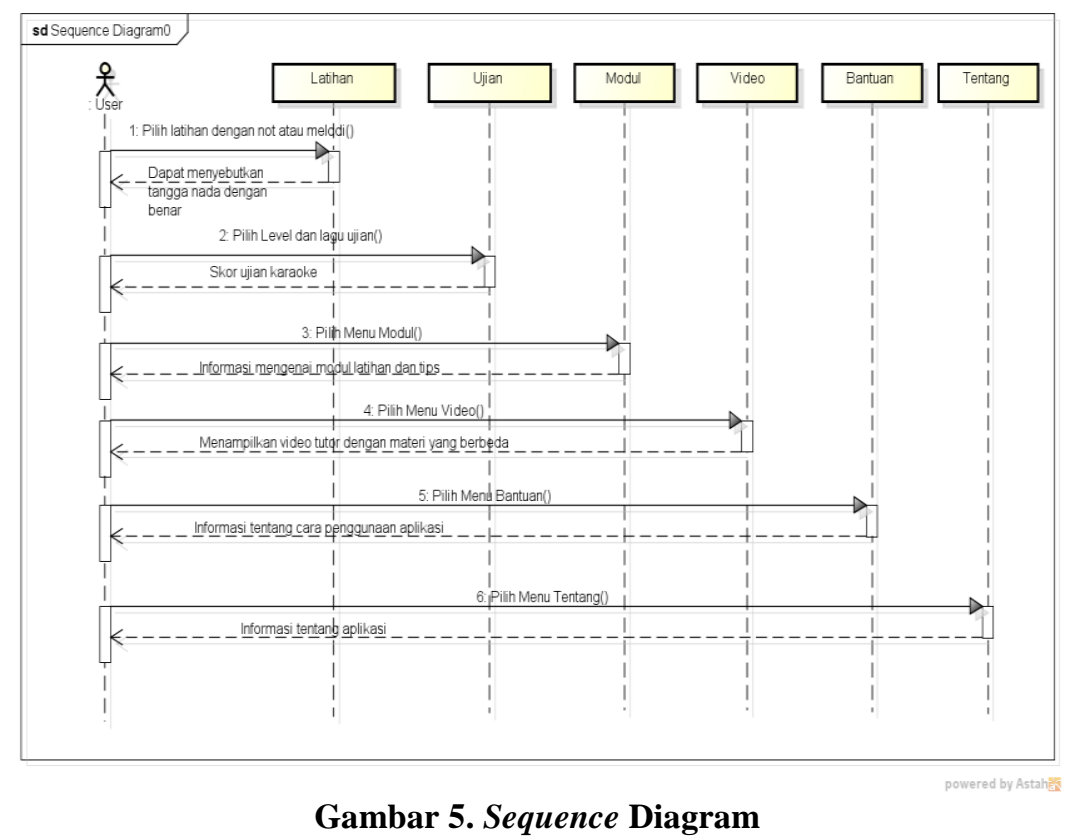

Pada diagram diatas, adalah interaksi antara pengguna dengan sistem. Pengguna masuk pada menu utama kemudian pilih menu latihan untuk mempelajari tentang teknik pengucapan nada, kemudain pada menu ujian sistem akan memberikan hasil dari pengujian bernyanyi. Kemudian pada menu modul, pengguna dapat mengetahui tentang teknik vokal dan tips secra teori, sedangkan pada menu video pengguna dapat melihat video tutr mnegnai teknik vokal secara praktek. Lalu pengguna memilih menu bantuan dimana berisi tentang informasi penggunaan aplikasi secara jelas. Yang terakhir pengguna memilih menu tentang, sistem akan memberikan informasi mengenai aplikasi tersebut.

\section{PEMBAHASAN}

\subsection{Implementasi Antarmuka}

\subsubsection{Menu Latih Vokal}

Pada aplikasi latih vokal ini, terdapat beberapa buah menu yang dapat dipiiih pengguna yakni, menu latihan, ujian, modul, video, bantuan dan tentang. Menu latihan dan ujian merupakan menu penting dalam aplikasi ini, karena pada kedua menu tersebut masing-masing menggunakan metode Harmonic Product Spectrum (HPS) dan Boyer Moore dalam penilaiannya. Gambar 6 dibawah ini merupakan tampilan menu yang bisa dipilih. 


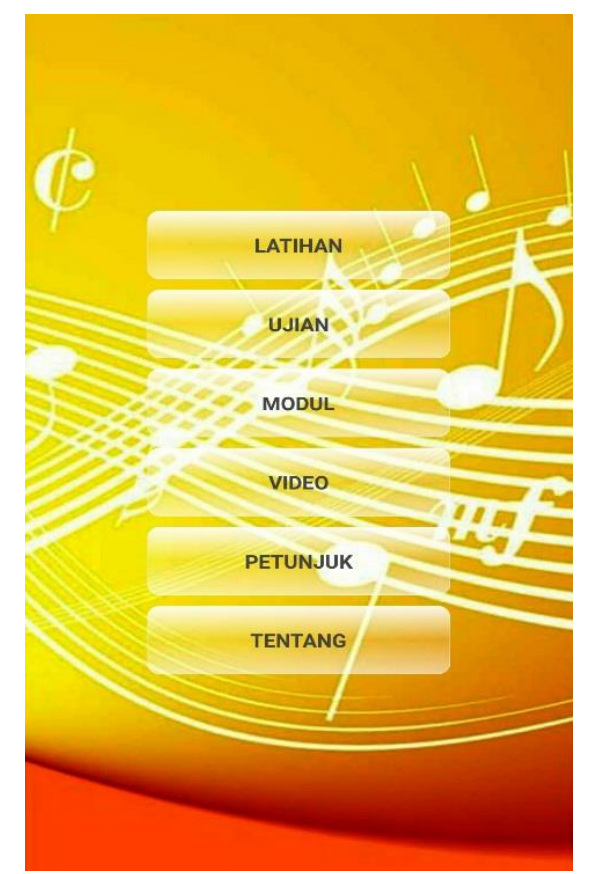

Gambar 6. Tampilan Menu Latih Vokal

\subsubsection{Menu Latihan}

Pada menu latihan terdapat dua pilihan menu yang bisa dipilih oleh pengguna yaitu latihan dengan not atau latihan dengan melodi. Latihan dengan not yaitu pengguna dapat memahami nada dasar atau tangga nada secara satu persatu, aplikasi akan merekam setiap nada yang diucapkan berdasarkan nada yang diberikan, Kemudian aplikasi akan memberitahu apakah nada yang diucapkan benar atau salah. Apabila nada yang diucapkan salah, maka aplikasi akan terus mengulang nada sampai nada tersebut berhasil di ucapkan dengan benar, dan jika benar maka akan aplikasi akan menampilkan nada yang lain.

Latihan dengan melodi hampir sama dengan latihan dengan not, yang membedakan adalah pada latihan ini pengguna langsung menyebutkan tangga nada secara keseluruhan "do re mi fa sol la si". Aplikasi juga akan merekam suara pengguna dan memberikan hasil pada bagian nada mana yang salah. Pengguna dapat melakukan latihan secara berulang-ulang. Gambar 7 berikut ini merupakan tampilan untuk latihan dengan not.

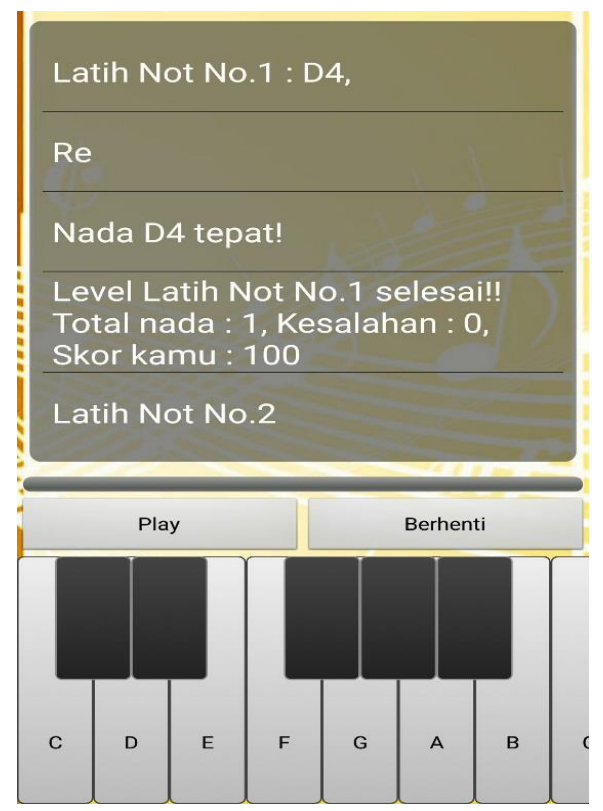

Gambar 7. Tampilan Menu Latihan Dengan Not 
Pada gambar 7 diatas merupakan tampilan menu latihan dengan not. Setelah menekan tombol "play" pada layar maka nada yang diberikan akan muncul. Nada yang diberikan adalah "re" maka pengguna menyebutkan nada tersebut sesuai dengan bunyi nada yang terdengar dari aplikasi. Apabila benar, maka akan tampil seperti gambar diatas, namun jika nada salah akan keluar pemberitahuan bahwa nada salah. Begitu juga latihan dengan melodi, yang berbeda hanyalah akan muncul pemberitahuan nada yang salah, jika semua nada benar maka yang muncul adalah nada salah $=0$ berarti semua nada di tangga nada tersebut benar. Berikut ini gambar 8 merupakan tampilan latihan dengan melodi.

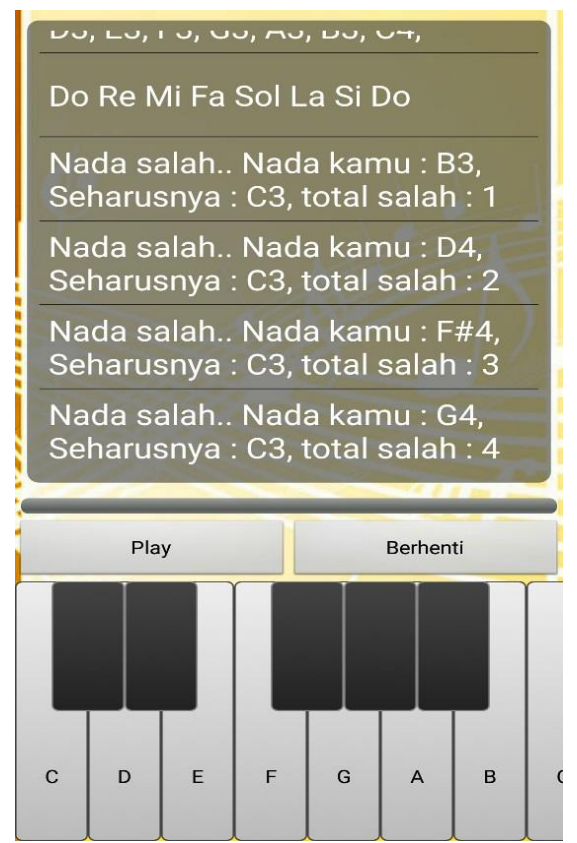

Gambar 8. Tampilan Menu Latihan Dengan Melodi

Pada gambar 8 merupakan tampilan menu latihan dengan melodi. Terlihat bahwa pada tangga nada "do re mi fa sol la si do" terdapat 4 buah kesalahan dari 7 nada dalam penyebutannya yakni pada nada b3 atau sama dengan nada "si", nada d4 atau sama dengan nada "re", nada f\#4 atau sama dengan nada "fa" dan nada g4 sama dengan nada "sol". Pengguna dapat mengulangi latihan dengan not atau melodi sampai pengucapan nada dianggap benar dan pengguna merasa sudah cukup menguasai latihan tersebut.

Metode yang bekerja pada proses latihan dengan not dan dengan melodi ini menggunakan metode Harmonic Product Spectrum (HPS). Metode Harmonic Product Spectrum (HPS) pada aplikasi digunakan dalam proses pendeteksian nada yang di inputkan. File suara berisi rekaman suara yang menyebutkan tangga nada, sehingga dalam satu file suara tersebut terdapat nada yang akan diidentifikasi. Setelah itu sinyal suara tersebut akan diproses dengan algoritma Harmonic Product Spectrum dimana kita membagi sinyal input ke segmen dengan menerapkan jendela Hanning (segemen-segmen sinyal input), ukuran jendela dan ukuran hop diberikan sebagai masukan. Untuk setiap jendela, kita memanfaatkan Short-Time Fourier Transform untuk mengubah sinyal masukan dari domain waktu ke domain frekuensi.

Setelah input dalam domain frekuensi, lalu diterapkan teknik Spectrum Produk Harmonic ke setiap jendela. Tahapan pertama dalam algoritma Harmonic Product Spectrum ini adalah proses FFT (Fast Fourier Transform) yaitu sinyal dalam domain waktu kemudian diubah ke domain frekuensi untuk melihat range frekuensinya. Proses ini bertujuan untuk menentukan range frekuensi yang memiliki energi paling maksimum. Setelah sinyal dalam domain frekuensi, frekuensi ini lah yang akan digunakan untuk pendeteksian nada yang muncul. Berikut ini merupakan potongan source code metode Harmonic Product Spectrum (HPS).

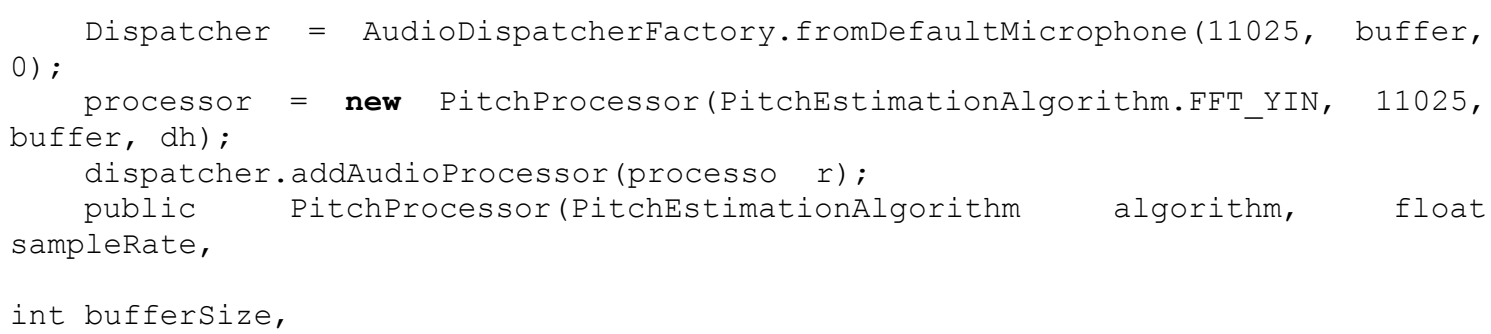




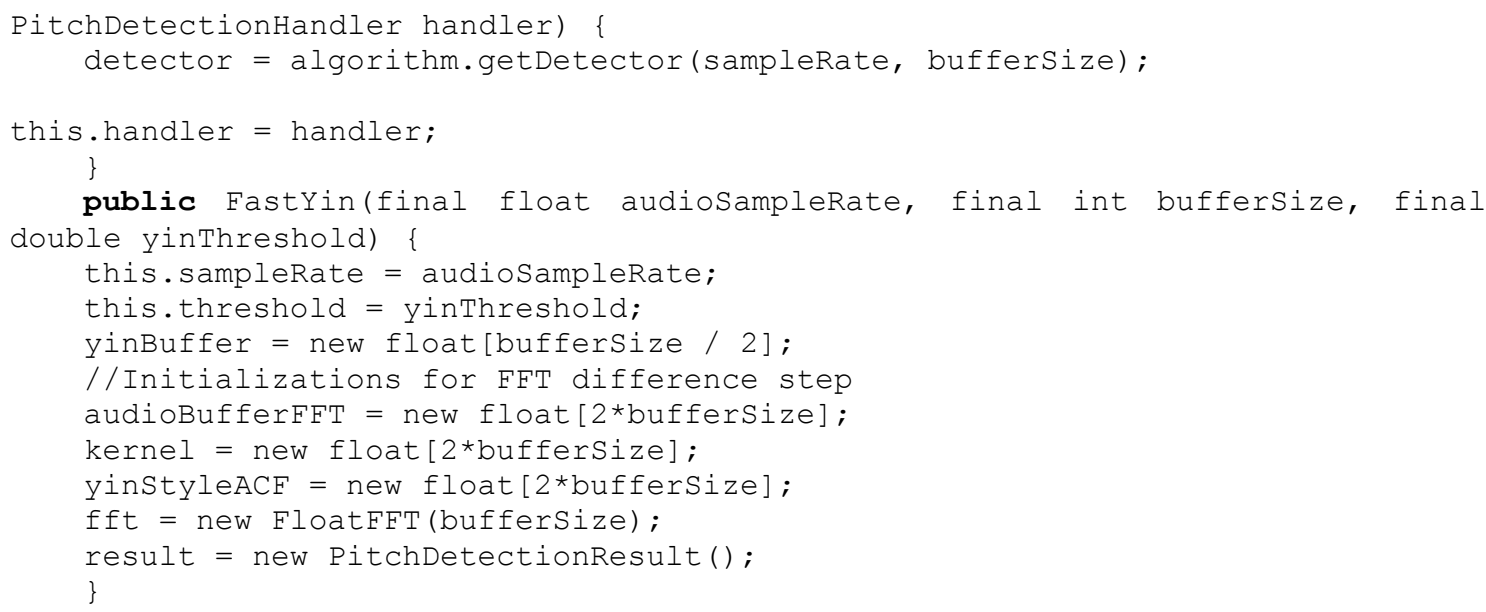

Pada source code diatas merupakan code untuk proses pendeteksian pitch. FFT_YIN merupakan salah satu algoritma yang bisa digunakan pada metode Harmonic Product Spectrum (HPS). Untuk aplikasi ini menggunakan algoritma Dynamic Wavelet atau FFT_YIN. Algoritma yang bisa dipakai banyak, tetapi algoritma yang dipilih merupakan algoritma yang paling cepat untuk nada realtime. Pada aplikasi ini menggunakan library tarsosDSP (Digital Sound Processing) untuk memproses suara inputan.

\subsubsection{Menu Ujian}

Halaman ujian adalah menu yang dapat dipilih oleh pengguna dengan tiga pilihan level yaitu mudah, sedang dan sulit. Pada setiap menu terdapat satu lagu berbeda yang bisa dinyanyikan. Untuk level mudah terdapat lagu Satu Nusa Satu Bangsa, Level sedang adalah lagu Aku Bukan Bang Toyib dan Level sulit adalah lagu Matahariku. Lagu-lagu tersebut dipilih berdasarkan tingkat kesulitan yang dilihat dari banyaknya perpindahan nada atau improve nada, baik itu perpindahan dari nada rendah ke tinggi atau dari nada tinggi ke rendah. Lagu satu Nusa Satu Bangsa dipilih sebagai lagu pada level mudah karena lagu tersebut tidak memiliki improve nada yang banyak dibanding lagu aku bukan bang toyib pada level sedang dan lagu matahariku pada level sulit yang memiliki perpindahan nada dan improve nada. Ujian ini bertujuan untuk melihat sejauh mana teknik vokal yang sudah dikuasai oleh pengguna. Nantinya setelah pengguna selesai menyanyikan sebuah lagu, aplikasi akan memberikan hasil berupa skor dari lagu yang dinyanyikan. Berikut merupakan gambar 9 tampilan menu ujian setelah tombol "play".

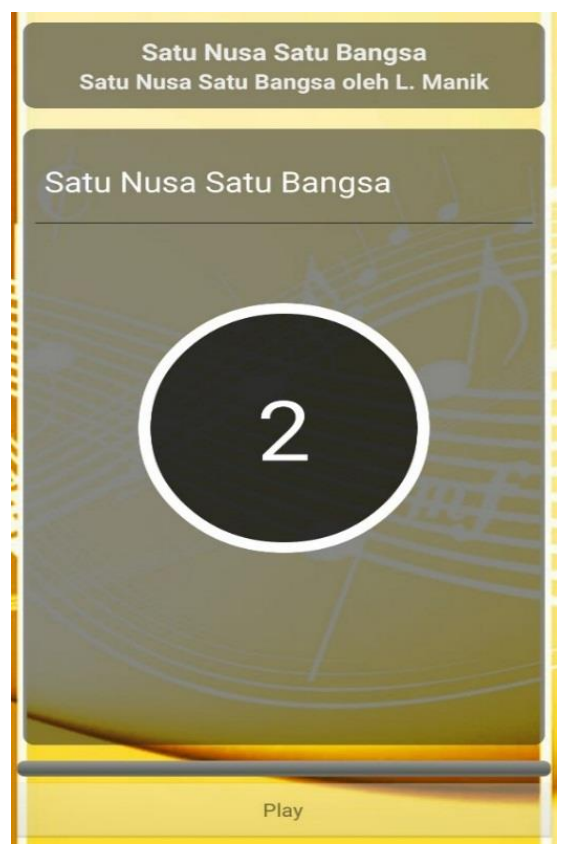

Gambar 9. Tampilan Menu Ujian Setelah Tombol Play 
Pada gambar 9 merupakan tampilan menu ujian setelah memilih level. Lagu satu nusa satu bangsa diatas merupakan lagu untuk pilhan level mudah. Pengguna dapat menekan tombol play sebelum karaoke dimulai. Setelah pengguna selesai menyanyikan lagu tersebut maka akan muncul skor dari lagu yang dinyanyikan. Berikut ini gambar 10 merupakan tampilan untuk skor karaoke.

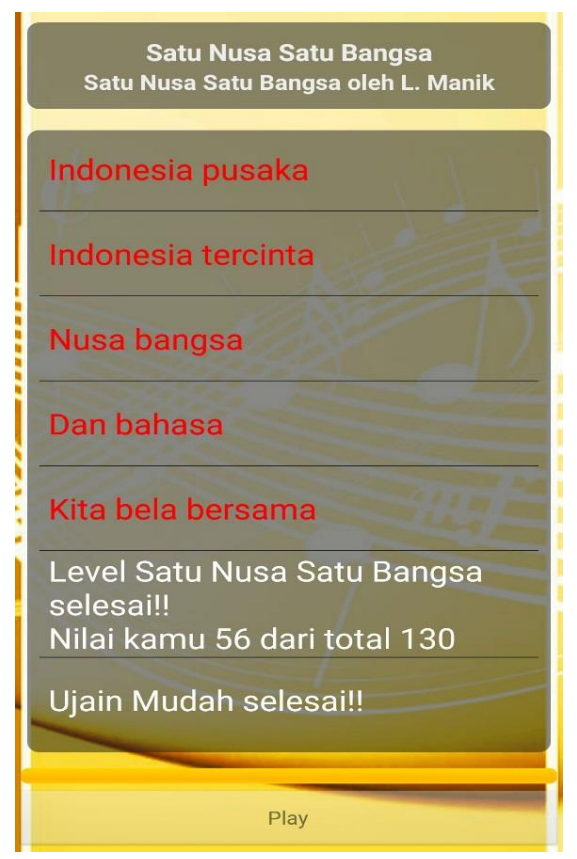

Gambar 10. Tampilan Skor Ujian

Pada gambar 10 diatas adalah tampilan skor ujian karaoke dimana nilai yang di dapat adalah 53 dari total nada 130, artinya dari 130 nada pada lagu tersebut pengguna dapat menyebutkan 56 nada yang benar dan 74 nada yang salah. Pengguna juga dapat mengulangi ujian bernyanyi sampai benar-benar mengusai lagu tersebut dengan pengucapan nada yang tepat, sehingga kesalahan nada pada lagu berkurang.

Metode yang digunakan untuk proses skoring ujian karaoke ini menggunakan metode Boyer Moore. Metode Boyer Moore pada aplikasi digunakan dalam proses penentuan skor ujian bernyanyi. Pencarian Boyer Moore merupakan pencocokan string, dimana dalam penelitian ini pencocokan string yang dimaksudkan adalah pencocokan nada-nada perliriknya. Untuk penetuan skor pada ujian, dimana misalnya dalam satu bait nadanya CDEFGAB. Dari nada tersebut nada c, de dan gab benar. Pada saat pencarian pattern, c tidak diangap sebagai pattern karna terdiri dari 1 nada yang disebut patttern apabila terdiri dari 2 atau 3 nada. De dan gab benar, maka akan mencari semua de dan gab dilirik yang lain dan juga dianggapbenar. Seandainya di lirik laain pada nada de atau gab fals, nada tersebut masih dianggap benar karena jika dia berhasil menyenyikan di nada tersebut dengan baik dan benar pada lirik sebelumnya maka dianggap sudah bisa menyanyikan perpindahan nada dari d ke e. Berikut ini merupakan potongan source code dari metode Boyer Moore.

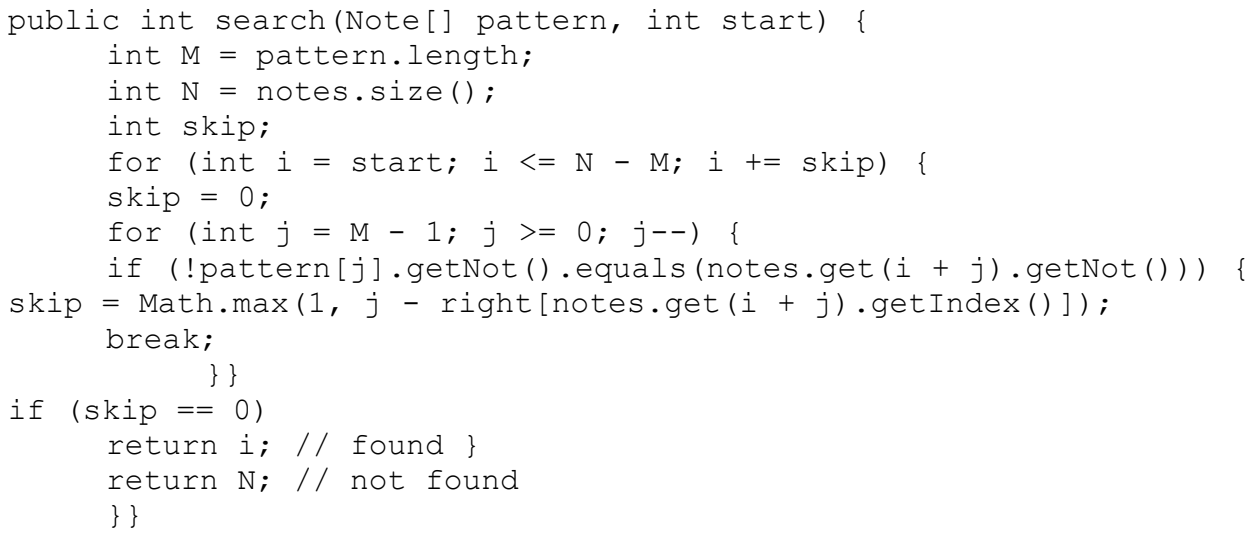

Potongan source code diatas merupakan proses metode Boyer Moore dalam pencocokan pattern. Pattern note yang tersimpan dalam array akan dicari di barisan nada lagu. Dimana dikatakan pattern 
apabila terdiri dari 2 atau 3 not. Sistem akan melakukan looping atau perulangan pencarian pattern pada note hingga semua keluaran pattern ditemukan.

\section{KESIMPULAN}

Berdasarkan analisa perancangan sistem, implemantasi, dan pengujian sistem, maka dapat disimpulkan bahwa:

1) Penelitian ini telah berhasil menghasilkan aplikasi latih vokal berbasis android. Sistem ini dapat digunakan oleh pengguna untuk membantu memberikan pelatihan vokal secara otodidak dan praktis dengan menggunakan metode HPS (Harmonic Product Spectrum) dan Boyer Moore.

2) Berdasarkan hasil pengujian black box yang dilakukan dengan teknik equivalence partitioning, yaitu teknik pengujian yang membagi domain input, menentukan kasus pengujian dengan mengungkapkan kelas-kelas kesalahan dianggap telah berhasil dalam menguji metode HPS (Harmonic Product Spectrum) dan Boyer Moore pada aplikasi latih vokal.

3) Sistem ini dapat memberikan kemudahan kepada pengguna dan layak dalam pembelajaran latih vokal. Dalam pengujian kemudahanan sistem, didapatkan hasil penilaian, yaitu kemudahan dalam penggunaan sistem berfungsi dengan baik dengan presentase nilai $65 \%$. Kemudahan dalam tampilan berfungsi dengan baik dengan presentase nilai $69 \%$, dan kemudahan dalam menampilkan isi dari aplikasi baik dengan presentase nilai $68.05 \%$. Dalam pengujian kelayakan sistem didapatkan hasil penilaian, yaitu fungsi-fungsi dalam sistem berfungsi dengan baik dengan presentase nilai $68.33 \%$, antarmuka dan pengaksesan sistem baik dengan presentase nilai $67.05 \%$, dan manfaat sistem baik dengan presentase nilai $69.33 \%$ sehingga sistem bermanfaat untuk pengguna.

\section{SARAN}

Berdasarkan analisa perancangan sistem, implementasi, dan pengujian sistem, maka untuk pengembangan penelitian selanjutnya penulis menyarankan sebagai berikut:

1) Sistem ini dapat terus dikembangkan lebih lanjut dalam hal metode yang digunakan, kedepannya diharapkan untuk dapat menggunakan metode selain metode HPS (Harmonic Product Spectrum) dan Boyer Moore dalam pendeteksian nada serta skoring pada aplikasi latih vokal.

2) Sistem ini dapat dilakukan pengembangan dengan penambahan lagu untuk setiap level dan penambahan pengenalan nada yang lebih luas.

3) Sistem ini juga dapat dilakukan pengembangan dengan menampilkan nada-nada yang salah pada saat ujian bernyanyi, sehingga pengguna dapat mengetahui bagian nada yang salah dari tiap lirik pada lagu tersebut.

\section{DAFTAR PUSTAKA}

[1] Middleton, Garreth (2003). Pitch Detection Algorithm.DOI=http://cnx.org/content/m11714/latest/

[2] Bayu Satya, DS. (2013). Teknik Dasar Bernyanyi. Yogyakarta: Penerbit ANDI

[3] Yanuar Christian Ardianto, Liliana, M.Eng, Gregorius Satia Budi. 2012. Perancangan dan Pembuatan Aplikasi Pengenal Nada Dasar Pada File Lagu Monophonic, Jurusan Teknik Informatika, Fakultas Teknologi Industri, Universitas Kristen Petra.

[4] McClellan, Schafer, Yoder. (2003). Signal Processing First. Prentince Hall.

[5] Edward Rompah. Handbook of Exact String Matching Algorithm. 2001.

[6] Satyaputra, A., Aritonang, \& Maulina, E. (2012). JAVA for Beginners with eclipse 4.2 JUNO. Jakarta: PT. Elex Media Komputindo.

[7] Widodo, P. P., \& Herlawati. (2011). Menggunakan UML. Bandung: Informatika.

[8] Lewis, W. E. (2005). Software Testing and Continuous Quality Improvement Second Edition. Boca Raton London New York Wahington, D.C.: CRC Press LLC.

[9] Samuel, Jefry Muliawan, Andika Nugraha. 2013. Analisis dan Perancangan Aplikasi Latih Vokal Berbasis game Android, Jurusan Teknik Informatika, Universitas Bina Nusantara.

[10] Tedy Gumilar, Drs.Suwandi, Hertiana. 2012. Deteksi Nada Pada String Gitar Dengan Menggunakan Harmonic Product Spectrum, Jurusan Teknik Fisika, Fakultas Teknik, Universitas Telkom Bandung.

[11] Taufik Hidayat. 2013. Penerapan Algoritma Boyer Moore untuk Penentuan Score pada Mesin Karaoke, Jurusan Teknik Informatika, Fakultas Teknik, Institut Teknologi Bandung.

[12] Irvan Hadyansyah, Gelar Budiman, Unang Sunarya. 2013. Aplikasi Identifikasi Nada Suara Manusia Menggunakan Metode FFT Berbasis Android, Jurusan Teknik Telekomunikasi, Fakultas Teknik Elektro, Universitas Telkom. 